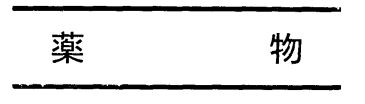

\title{
慢性副鼻腔炎患者におけるブロンカスマ・
}

\section{ベルナネブライザー療法の鼻粘膜線毛運動 に及ばす影響に関する研究}

\author{
大橋 淑宏 1 - 中井義明 1 ) - 武市 直範 2 \\ 池岡 博之 ${ }^{3}$ ・古下 博之 ${ }^{1}$ 。江崎 裕介 ${ }^{1}$ \\ 加藤 匠子 1 ・加藤 元章 $\mathbf{1}$
}

\section{The Influence of Ultrasonic Nebulization with Broncasma Berna on the Nasal Mucociliary Movement in Patients with Chronic Sinusitis}

\author{
Yoshihiro Ohashi, Yoshiaki Nakai, Hiroyuki Koshimo, \\ Yusuke Esaki, Shoko Kato and Motoaki Kato \\ (Osaka City University) \\ Naonori Takeichi \\ (Osaka Municipal Kita Citizens Hospital) \\ Hiroshi Ikeoka \\ (Yodogawa Christian Hospital)
}

Using an ultrasonic nebulizer, $6 \mathrm{ml}$ of Broncasma Berna solution diluted 12-fold with saline was given intranasally at a single dose to 15 patients with chronic sinusitis two or three times a week over a period of 4 weeks, and the ciliary movement of the nasal mucosa before and after the treatment was measured. Ciliary movement was increased markedly in 7 patients, and slightly in 7 but was slightly decrease in 1 .

Nebulization with Broncasma Berna was found to enhance nasal mucociliary movement.

Key words: Broncasma Berna, chronic sinusitis, nasal mucociliary movement, ultrasonic nebulization

2) 大阪市立北市民病院耳鼻咽喉科

3）淀川キリスト教病院耳鼻咽喉科 


\section{緒言}

慢性副鼻空炎の薬物療法として，ネブライザ 一療法が繁用されている.内服療法の場合と比 較すると，ネブライザ一療法では全身に与える 影響が少なくかつ高濃度に薬物を鼻・副鼻腔に 移行しうるなどの利点がある。しかし，薬物を エアロゾルとして用いる際には，その楽物の鼻 ・副鼻腔粘膜に与える影響, 特に粘液線毛系に 及ぼす影響についても考慮することが重要であ る.

本研究に求いては，8種類の上気道常在菌の 死菌ワクチンであるブロンカスマ・ベルナを用 いたネブライザー療法の鼻粘膜線毛運動に及ほ す影響について検討した。

\section{対象および方法}

昭和61年 4 月から 6 月の間に著者らの施設を 受診した慢性副鼻空炎患者で本研究への参加に 同意した15名を対象とした。なお，急性增悪期 や鼻茸症を伴なうあのおよび重篤な合併症を有 する症例は除外対象とした。 $4 \%$ キシロカイン および $0.1 \%$ ボスミンスプレーによる鼻処置を
施行後に，ブロンカスマ・ベルナ希釈液を超音 波ネブライザーを用いてエアロゾルとして経鼻 的に投与した. 投与速度は每分 $2 \mathrm{ml}$, 投与回数 は $2 \sim 3$ 回/週とし，投与期間は 4 週間とし た。なお，本ネブライザー療法に㧊いては，ブ ロンカスマ・ベルナ原液 $1 \mathrm{ml}$ 生理食塩液で希 釈し $12 \mathrm{ml}$ とした液のうち $6 \mathrm{ml} 1$ 回量として使 用した。

本ネブライザー療法開始前および本療法終了 3 日後に右下鼻甲介中央部の粘膜より 4 個の生 検材料をそれぞれ採取し，大橋・中井の photoelectric method $^{12)}$ を用いて，その線毛運 動数を測定した.

\section{成 績}

本ネブライザー療法による右下鼻甲介粘膜の 線毛運動数の変動を図 1 亿示した. 1 症例（症 例№. 8 ) を除く14症例で平均線毛運動数の増加 が観察された。また，15症例中 7 症例（症例 №. 2，4，6，7，9，11，13）では，本療法後に は線毛運動数の有意の増加が認められた $(\mathrm{p}<$ 0.05).なお，本療法後に線毛運動数が有意に

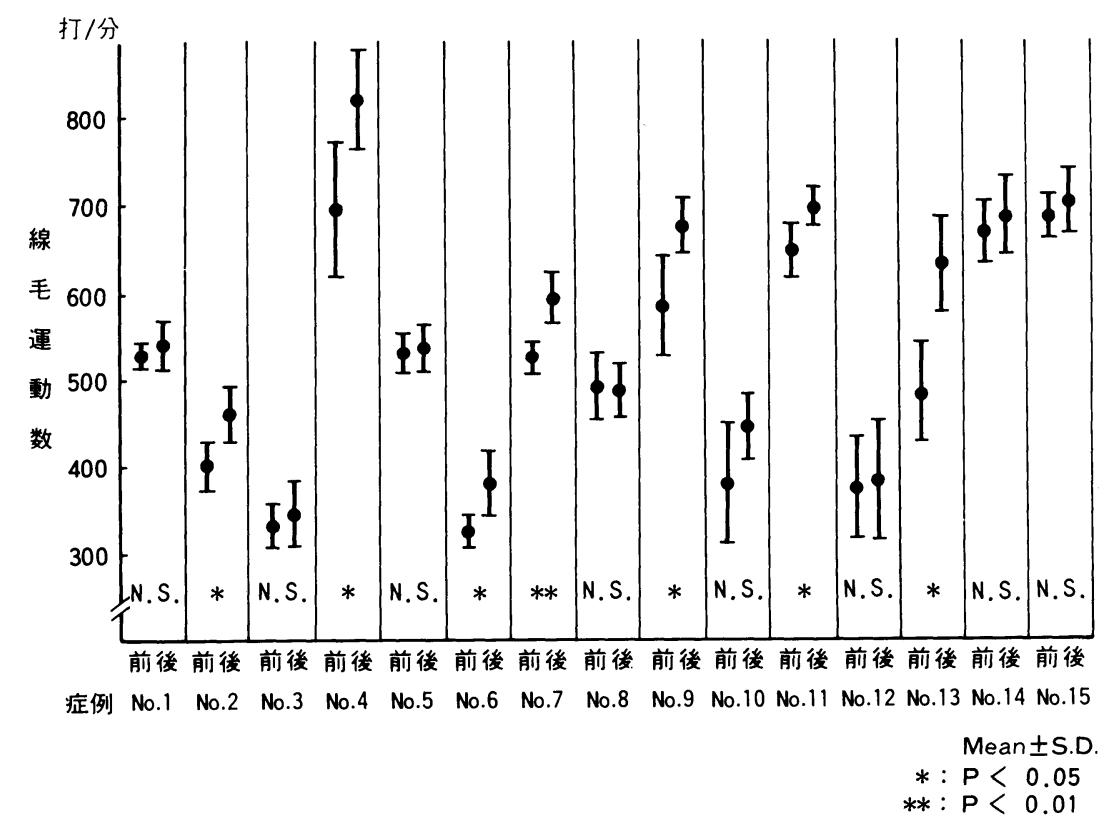

図 I ブロンカスマ・ベルナのネブライザー療法による治療前後の線毛運動数の変動 
低下した症例は㫮無であった。 また，15症例の 平均線毛運動数を本療法の前後で群間比較した 場合には, 危険率 0.0001 以下で線毛運動数の有 意な増加が認められた（図 2 ）。

\section{考察}

慢性副鼻空炎の治療は楽物療法之観血的療法 とに大別される. 薬物療法では抗生剂や蛋白分 解酵素が主体となっているが，乙れまでの治療 法には限界がある. 慢性副鼻腔炎の病因は感染 あるいは炎症と考えられてきたが，アレルギー の関与が近年示唆されている3). しかし, アレ ルギー因子として即時型の関与は比較的少な (4). 石川, 馬場らはその成因として細菌抗原 による而型アレルギーの関与を指摘し, 古内 はI型アレルギー関与を報告している ${ }^{5) \sim 7)}$. 本疾患を有する患者では Staphylococcus aureus, epidermidis の皮内試験で高い陽性 率が得られたとの報告もあり ${ }^{8)}$, 細菌による中

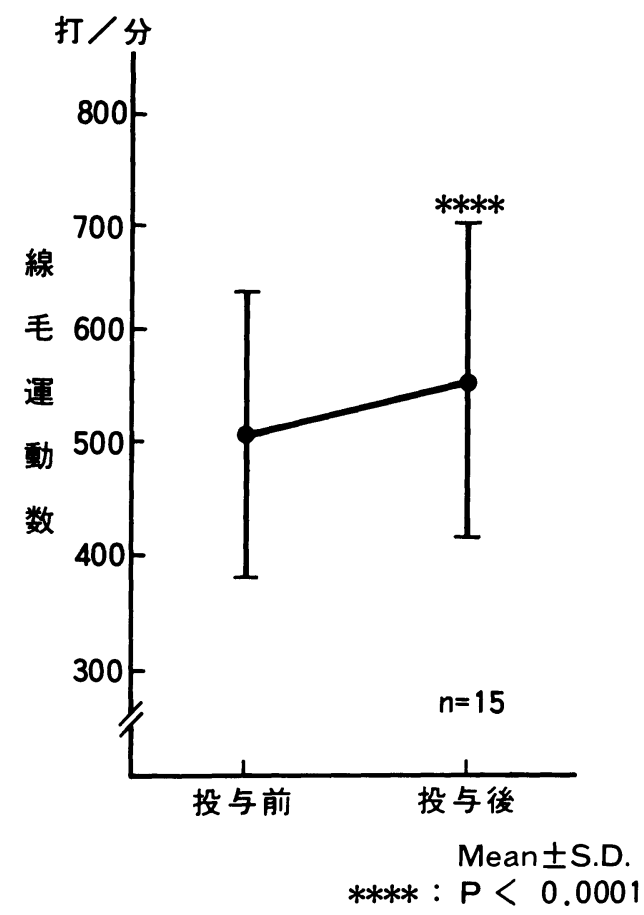

図 2 ブロンカスマ・ベルナのネブラ.イザー療法 による平均線毛運動数の変動
間型あるいは遅延型アレルギーが慢性副鼻腔炎 の発症や慢性化の原因となっている可能性む 高い. てのような点より考えて, 慢性副鼻腔炎 の治療に細菌ワクチンが有効であるととが期待 されうる.

てれまで多施設において多種死菌ワクチン （ブロンカスマ・ベルナ）が慢性副鼻腔炎の治 療に試みられ，いずれの施設に㧊いても良好な 成績が報告されている(10).

一方, 最近では種々の注射剂をエアロゾルと して投与するてとが試みられ，鼻疾患や副鼻腔 疾患に高い有効率を示すことが報告されてい る. ブロンカスマ・ベルナもてれまでにいくつ かの施設に㧊いてエアロゾルとして慢性副鼻腔 炎の治療に導入されており，有効であるとの報 告が見られる ${ }^{11121}$. ネブライザー療法において は，内服療法や注射療法の場合と比較して全身 に及ぼす影響が少ないとと，高濃度の薬物を鼻 ・副鼻腔に到達させうること，また疼痛を伴な わないので幼小児にも投与が容易であることな どの利点が多い. しかし, 使用する薬物の鼻・ 副鼻腔粘膜に及ぼす影響, 特に粘膜線毛運動系 に及ぼす影響を考慮することが必要と考えられ る.

粘液線毛系は種々の外的因子より気道粘膜を 保護する役割を担っているが, 種々の薬物や化 学因子に脆弱であることが知られている.ま た, 鼻アレルギーや慢性副鼻腔炎の鼻副鼻腔粘 膜では線毛運動の低下していることが指摘され ており, 線毛運動機能低下がこれら疾患の難治 性の一因子となっている(11314). したがって, 慢性副鼻腔炎などの鼻副鼻腔疾患に用いるエア ロゾル剂が鼻副鼻腔の粘液線毛運動を障害しな いことが必要である.

本研究においては, ブロンカスマ・ベルナの ネブライザー療法後に鼻粘膜の線毛運動数の低 下が認められなかった. したがって，本剂をエ アロゾルとして利用するととは充分に可能であ ると考えられる．また，いくつかの症例ではむ しろ線毛状態の賦活が観察された.すで著者 
らはある種の $\beta$-stimulant が線毛運動を賦活 するととを観察し，これをエアロゾルとして臨 床応用し良好な成績を認めている ${ }^{15)}$ 。 ての点よ り考えて，ブロンカスマ・ベルナのネブライザ 一療法むまた隐床的に良好な成績を示す可能性 屯高い之考えられる.

\section{まとめ}

1. 慢性副鼻腔炎患者15名に対してブロンカ スマ・ベルナ12倍希釈液 $6 \mathrm{ml} 1$ 回量とし超音 波ネブライザーを用いて $2 \sim 3$ 回/週， 4 週間 鼻腔内投与し，治療前後に鼻粘膜を採取してそ の線毛運動数を計測した.

2. 全症例中 7 例において線毛運動数の有意 な増加が，他の 7 例において増加傾向が認めら れた。1例においてわずかに低下したが，有意 ではなかった。

3. ブロンカスマ・ベルナのネブライザー療 法は鼻粘膜の線毛運動を障害する作用はなく， むしろてれを賦活する傾向のあるてとが認めら れた。

\section{参考文献}

1) Ohashi Y and Nakai Y : Functional and morphological studies on chronic sinusitis mucous membrane. 1. Decline of ciliary action in chronic sinusitis. Acta Otolaryngol (Stockh) Suppl 397: 3 9, 1983.

2) Ohashi Y and Nakai Y : Mucociliary activities in fetal rabbits. Acta Otolaryogol (Stockh) $97: 351 \sim 358,1984$.

3 ) Hansel FK : Clinical Allergy. The CV Mosby Co., 1953.

4 ）奥田 稔, 浅野佳徳, 関根啓一：鼻粘膜炎症と体 質をめぐる問題（その 8$)$ 慢性副鼻腔炎とアトピ 一型アレルギーについて. 耳喉 $37: 731 \sim 740$, 1965.

5 ）石川 哮：慢性副鼻腔炎患者副鼻腔粘膜ブドウ球 菌抗体の分布. 日本鼻副鼻腔学会会誌 $13: 9$ 〜 $10,1974$.

6 ）三村幸弘, 岩田重信, 馬場駿吉, 他 : 家鬼副鼻腔 粘膜に扔ける緑膿菌の抗原性に関する研究. 日本
舅副鼻腔学会会誌 $11: 75 \sim 76,1973$.

7 ) 古内一郎：遅延型アレルギー(細胞免疫：N型） の立場より. 日本鼻副鼻腔学会会誌 $13: 10 \sim$ $11,1974$.

8 ）古内一郎, 馬場広太郎, 奥沢裕二, 他：鼻副悬腔 炎に対する細菌抗原の皮内反応成績について。 レルギー $25: 300 〜 301 ， 1976$.

9 ）水越 治, 佐藤良暢, 坂口富美, 他：Broncasma Berna による慢性副鼻腔炎および鼻アレ ルギーの治療成績集計.耳鼻臨床 $68: 1477$ 1485, 1975.

10）武田一雄, 高橋宏明, 中村文昭, 他：慢性副鼻腔 炎および鼾アレルギー患者汇対する Broncasma Berna の使用経験。䧐療と新薬 $13: 1109$ ～ 1118, 1976.

11）和田 清, 納谷 裕, 田口喜一郎：慢性副悬腔炎 に対する細菌性多価抗原製剤 Broncasma Berna によるエアロゾル燎法の検討. 耳展 $28: 199$ 208, 1985.

12）藤谷哲造, 森本大和, 前田 仁：鼻アレルギー, 慢性副鼻腔炎に対するブロンカスマ・ベルナによ るエアロゾル療法の検討. 新薬と臨床 $33: 703$ 713, 1984.

13) Ohashi $Y$ and Nakai $Y$ : Functional and morphological studies on chronic sinusitis mucous membrane. 2. Functional and morphological pathology of chronic sinusitis mucous membrane. Acta Otolaryngol (Stockh) Suppl $397:$ 11 48, 1983.

14) Ohashi $Y$, Nakai $Y$, Kihara $S$, et al : Ciliary activity in patients with nasal allergies. Arch Otorhinolaryngol $242: 141 \sim 147$, 1985.

15) Ohashi $Y$, Nakai $Y$, Zushi K, et al : Functional and morphological studies on chronic sinusitis mucous membrane. 3. Enhancement of ciliary action by a $\beta$-adrenergic stimulant. Acta Otolaryngol (Stockh) Suppl $397:$ 49 59, 1983.

\footnotetext{
原稿採択：昭和62年 8 月 7 日 急載 別刷請求先：大橋淑宏

厂545大阪市阿倍野区旭町 1-4-54 大阪市立大学医学部耳鼻咽喉科学教室）
} 